\title{
Trehalose in Three Species of Desiccation Tolerant Tardigrades
}

\author{
K. Ingemar Jönsson ${ }^{*, 1,2}$ and Ola Persson ${ }^{1}$ \\ ${ }^{1}$ School of Teacher Education, Kristianstad University College, SE-291 88 Kristianstad, Sweden \\ ${ }^{2}$ Department of Genetics, Microbiology \& Toxicology, Stockholm University, SE-106 91 Stockholm, Sweden
}

\begin{abstract}
We report a study on the presence of the disaccharide trehalose in three desiccation tolerant tardigrades. This sugar has long been suggested to play a protective role in desiccation tolerant animals. Trehalose was found in all species, with increased levels in dehydrated specimens of Macrobiotus islandicus, and possibly also in Macrobiotus krynauwi, both belonging to the family Macrobiotidae. In the third species, Milnesium tardigradum, very low amounts of trehalose were found, with no increase in the dehydrated state. This species has previously been reported to lack trehalose. Induction of trehalose has been reported only for species in the family Macrobiotidae, where also the highest levels have been found. Although the role of trehalose in the desiccation tolerance of tardigrades remains unclear, the diverging patterns in response to desiccation are interesting. Further studies of higher tardigrade taxa are needed in order to understand the evolutionary history of trehalose in these invertebrates.
\end{abstract}

Keywords: Anhydrobiosis, tardigrades, desiccation tolerance, trehalose, Milnesium tardigradum, Macrobiotus islandicus, Macrobiotus krynauwi.

\section{INTRODUCTION}

Revealing the biochemical mechanisms that allow cells to experience complete desiccation without permanent damage has been a major line of research in modern studies of organisms that are able to survive extreme desiccation, socalled anhydrobiotic organisms [1,2]. A particular focus has been on the non-reducing disaccharide trehalose, which has been found in a number of different anhydrobiotic invertebrates, e.g., nematodes $[3,4]$, tardigrades $[5,6]$, Artemia cysts [7], and larvae of the chironomid Polypedilum vanderplanki [8]. According to the "Water Replacement hypothesis", originally proposed by Webb [9], disaccharides or other polyhydroxy compounds play a protective role in desiccated cells by replacing removed water molecules connected to membranes and macromolecules. Among sugars, trehalose has a well documented advantage by a relatively high glass transition temperature $\left(\mathrm{T}_{\mathrm{g}}\right)$ and a low melting temperature $\left(\mathrm{T}_{\mathrm{m}}\right)$. The high $\mathrm{T}_{\mathrm{g}}$ may maintain a stable glassy state in the dry cell even at relatively high relative humidities, while the low $\mathrm{T}_{\mathrm{m}}$ avoids phase transition at rehydration of the cell [10-12]. Trehalose may not alone provide a sufficient protection against dehydration damage, however it has properties that makes it a better desiccation protectant than most other sugars, especially at sub-optimal conditions for dry storage [11].

Although trehalose is found in many anhydrobiotic organisms, it is not present in all species, and in fact seems to be completely absent in one of the three main taxa of anhydrobiotic organisms, bdelloid rotifers. Thus, in three species of anhydrobiotic bdelloid rotifers recently

*Address correspondence to this author at the School of Teacher Education, Kristianstad University College, SE-291 88 Kristianstad, Sweden; Tel: +46 44 203429; Fax: +46 44 203403; E-mail: ingemar.jonsson@hkr.se investigated, no signs of trehalose were found [13-15]. These observations are important, since they indicate that desiccation tolerance by involvement of trehalose is only one possible evolutionary pathway towards desiccation tolerance. Other organisms have obviously solved the same problem without the involvement of trehalose.

Tardigrades represent one of the three main groups where anhydrobiotic species are common, and two previous studies on disaccharides in anhydrobiotic tardigrades have been reported. Westh \& Ramløv [5] found a clear induction of trehalose by desiccation in the eutardigrade Richtersius coronifer, from $0.1 \%$ dry weight in the active state to $2.3 \%$ in the desiccated state. Hengherr et al. [6] reported that seven out of eight investigated tardigrade species contained trehalose, but only in species belonging to the Macrobiotidae family an increase of trehalose was observed in connection with desiccation. In this paper we extend the knowledge on trehalose in desiccation-tolerant tardigrades, by reporting analyses of trehalose in three species of tardigrades.

\section{MATERIALS AND METHODOLOGY}

\section{Collection and Animal Extraction}

Specimens of Milnesium tardigradum were extracted from moss (Orthotrichum cupulatum) and lichens (Xantoria parietina) collected at carbonite rock fences on the Baltic island Öland (see Jönsson et al. [16] for more details of the area of sampling). M. tardigradum was also collected from another site in southern Sweden, near the town Karlshamn (sun-exposed moss growing on concrete). The samples were kept dry at room temperature until extraction 1-2 months after collection. Moss samples containing Macrobiotus islandicus were collected near the Arctic Station at Disko Island, Greenland $\left(69^{\circ} 15^{\prime} \mathrm{N}, 53^{\circ} 34^{\prime} \mathrm{W}\right)$, in August 2000, and samples of gravel and sand containing Macrobiotus krynauwi were collected near the Swedish Antarctic base 
WASA $\left(73^{\circ} 2\right.$ S, $\left.13^{\circ} 25^{\prime} \mathrm{W}\right)$ in December 2001/January 2002. Samples of both M. islandicus and M. krynauwi were stored dry at $-20^{\circ} \mathrm{C}$ until extraction, a condition which ensured high long-term survival of the tardigrades.

Tardigrades from mosses were extracted during a $12-15 \mathrm{~h}$ period in plastic funnels filled with distilled water, where moss materials were placed in the top part on a metal net. By their natural body movements the tardigrades fall down through the water-filled funnel, ending up in an Eppendorf tube at the lower part of the funnel. Tardigrades from sand/gravel samples from Antarctica were extracted by sieves. Tardigrades used for hydrated samples were kept hydrated for 15 hours before preparation.

\section{Desiccation Procedure}

Samples of tardigrades (with a range of 162-200 specimens/sample for $M$. islandicus, 65-130 for $M$. tardigradum, and 100-200 for M. krynauwi) were desiccated in aggregations in Eppendorf tubes at $20^{\circ} \mathrm{C}$ and $85 \%$ (most samples) or $94.6 \% \mathrm{RH}$ (four $M$. tardigradum samples), created by potassium chloride or potassium nitrate salt solution, respectively, in airtight desiccators. The different RH conditions used did not affect revival rate after desiccation, and survival control samples (one for each RH condition) with 10 individuals of each species revealed a near $100 \%$ survival.

\section{Preparation for Gas Chromatography}

To an Eppendorf tube with desiccated animals was added $200 \mu 140 \%$ aqueous ethanol. The tube was heated in $100{ }^{\circ} \mathrm{C}$ water for one minute and the contents were then transferred to a tissue grinder (Kontes Glass Co., size 21) and disintegrated for one minute. The resulting mixture was transferred back to the Eppendorf tube and combined with two portions of $50 \mu \mathrm{l} 40 \%$ ethanol that were used to rinse the tissue grinder. After centrifugation for three minutes at $14.5 \times 1000 \mathrm{rpm}$ in a Minispin Plus (Eppendorf), the supernatant was transferred to a new Eppendorf tube. To the remaining precipitate was added $200 \mu \mathrm{l} 95 \%$ aqueous ethanol. The tube was placed in an ultrasonic bath (Branson 2210) for one minute and the contents were then transferred to the tissue grinder. After disintegrating for one minute the contents were transferred back to the Eppendorf tube and centrifuged. The supernatant was collected and the precipitate was treated as described above with $200 \mu 120 \%$ aqueous ethanol.

The three supernatants were combined in an Eppendorf tube and dried in an oven at $80{ }^{\circ} \mathrm{C}$ over night. The contents were then sequentially dissolved with two portions of $50 \mu 1$ $20 \%$ and one portion of $95 \%$ ethanol and transferred to a glass vial together with $10 \mu \mathrm{g}$ of D-sorbitol (Sigma-Aldrich) dissolved in $20 \%$ aqueous ethanol. The samples were dried in an oven over night at $110{ }^{\circ} \mathrm{C}$ and then silylated with 100 $\mu \mathrm{l}$ Sigma-Sil-A (Sigma-Aldrich). The reaction mixtures were left at room temperature for at least 20 minutes before the GC-MS analyses.

\section{Gas Chromatography Analyses}

The silylated compounds were analysed using GC-MS (Finnigan-Trace, ThermoQuest). The column used was a BPX-5, $30 \mathrm{~m} \times 0.25 \mathrm{~mm}, \mathrm{SGE}$. D-sorbitol and D-trehalose
(Sigma-Aldrich) were silylated with Sigma-Sil-A and used as references. The chromatograms were analysed using the software Xcalibur ${ }^{\mathrm{TM}}$ (Home Page version 1.2). The quantitative analyses were based on the use of $10 \mu \mathrm{g}$ of Dsorbitol as an internal standard and the response factor for Dtrehalose/D-sorbitol was determined to be 1.07.

\section{Dry Weight Estimate}

Dry weight for $M$. tardigradum and $M$. islandicus were obtained by weighing samples of 60-100 specimens/sample (M. tardigradum, 4 replicates), or 194-199 (M. islandicus, 3 replicates) dry individuals on a Mettler Toledo MT5 micro balance. The animals were dehydrated in an Eppendorf tube in the laboratory $(40-50 \% \mathrm{RH})$ and the dry sample of animals was then carefully removed from the tube and transferred to a piece of glass, and measured on the micro balance. For M. krynauwi, calculation of dry weight was instead based on an estimate of average body volume in this species (assuming a tube shaped body) multiplied by the average specific weight of the related species $M$. $c f$. hufelandi (obtained from the same moss as M. tardigradum at Öland). Average specific weight of $M$. $c f$. hufelandi was obtained by measuring body volume and dry weight (using the protocol described above) in this species. From these estimates we obtained the following average dry weights: $1.06( \pm 0.16) \mu \mathrm{g}$ in $M$. tardigradum, $1.20( \pm 0.077) \mu \mathrm{g}$ in $M$. islandicus, and $0.23 \mu \mathrm{g}$ in M. krynauwi.

\section{RESULTS}

All tardigrade species contained trehalose (Table 1). In M. islandicus, dehydrated tardigrades had marginally significantly higher levels of trehalose (mean $=2.9 \%, 2.7-3.1$ $\%, \mathrm{SD}=0.21, \mathrm{~N}=3$ ) than hydrated tardigrades (mean $=0.41 \%$, 0.33-0.48 \%, SD=0.07, N=3; Mann-Whitney U-test: $\mathrm{U}=9.0$, $\mathrm{df}=1, \mathrm{P}=0.05$ ). Dehydrated $M$. krynauwi contained on average $2.3 \%$ trehalose $(0.44-4.4 \%, \mathrm{SD}=1.8, \mathrm{~N}=4)$. Too few specimens of $M$. krynauwi prevented analysis of hydrated animals. Dehydrated samples of $M$. tardigradum contained on average $0.077 \%(0.040-0.14 \%, \mathrm{SD}=0.046$, $\mathrm{N}=7$ ) trehalose, with no difference between the two collection sites (Öland: $0.070 \%, \quad \mathrm{SD}=0.040, \quad \mathrm{~N}=5$; Karlshamn: $0.095 \%, \mathrm{SD}=0.064, \mathrm{~N}=2$; Mann-Whitney Utest: $\mathrm{U}=2.5, \quad \mathrm{df}=1, \mathrm{P}=0.31)$. Hydrated samples of $M$. tardigradum contained $0.19 \%(0.060-0.32 \%, \mathrm{SD}=0.18$, $\mathrm{N}=2$ ) trehalose, and were not statistically different from the dry samples $(\mathrm{U}=3.0, \mathrm{df}=1, \mathrm{P}=0.23)$.

\section{DISCUSSION}

The result from M. islandicus confirms the results from previous studies (see Table 1) that species of the tardigrade family Macrobiotidae not only contain trehalose, but also tend to increase their levels of this sugar in connection with desiccation. Also the observed trehalose level in desiccated M. krynauwi supports this conclusion. Although trehalose levels in hydrated $M$. krynauwi were not investigated, no tardigrade species analyzed so far has contained levels as high as over $2 \%$ in the hydrated state, suggesting that this level was induced by desiccation. The increase in trehalose within Macrobiotidae ranges from 157-fold in the Macrobiotus "richtersi group" 2 [6] to 7-fold in M. tonollii [6] and M. islandicus (this study). In contrast, in neither $M$. tardigradum nor in species of the heterotardigrade family 
Table 1. Summary of Studies on Trehalose Levels in Active (Hydrated) and Anhydrobiotic Tardigrades

\begin{tabular}{|c|c|c|c|c|c|}
\hline Family & Species & $\begin{array}{l}\text { Trehalose in active } \\
\text { tardigrades }(\% \mathrm{dw})\end{array}$ & $\begin{array}{c}\text { Trehalose in anhydrobiotic } \\
\text { tardigrades }(\% \mathrm{dw})\end{array}$ & $\begin{array}{c}\text { Ratio Trehalose } \\
\text { Anhydrobiotic/ Active }\end{array}$ & References \\
\hline Macrobiotidae & Macrobiotus areolatus & $\begin{array}{l}\text { Present, but no } \\
\text { quantification }\end{array}$ & Present, but no quantification & - & [27] \\
\hline Macrobiotidae & Richtersius ${ }^{l}$ coronifer & 0.1 & 2.3 & $23^{2}$ & [5] \\
\hline Macrobiotidae & Macrobiotus islandicus & 0.41 & 2.9 & $7.1^{\mathrm{MS}}$ & This study \\
\hline Macrobiotidae & Macrobiotus krynauwi & - & 2.3 & - & This study \\
\hline Macrobiotidae & Macrobiotus tonollii & 0.022 & 0.153 & $7.0 * * *$ & {$[6]$} \\
\hline Macrobiotidae & Macrobiotus richtersi & 0.003 & 0.172 & $57.3^{* * *}$ & [6] \\
\hline Macrobiotidae & Macrobiotus sapiens & 0.011 & 0.087 & $7.9 * * *$ & {$[6]$} \\
\hline Macrobiotidae & Macrobiotus "richtersi group" 1 & 0.002 & 0.262 & $131.0^{* * *}$ & [6] \\
\hline Macrobiotidae & Macrobiotus "richtersi group" 2 & 0.003 & 0.472 & $157.3 * * *$ & {$[6]$} \\
\hline Echiniscidae & Echiniscus granulatus & 0.023 & 0.003 & $0.13^{\mathrm{NS}}$ & [6] \\
\hline Echiniscidae & Echiniscus testudo & 0.006 & 0.021 & $3.5^{\mathrm{NS}}$ & {$[6]$} \\
\hline Milnesidae & Milnesium tardigradum & 0 & 0 & - & [6] \\
\hline Milnesidae & Milnesium tardigradum & 0.19 & 0.077 & $0.41^{\mathrm{NS}}$ & This study \\
\hline
\end{tabular}

${ }^{1}$ This species was referred to as Adorybiotus coronifer in Westh \& Ramløv [5]. ${ }^{2}$ No statistical evaluation was made of differences between dehydrated and hydrated tardigrades. Statistical significances for comparisons between hydrated and dehydrated samples; NS: non-significant, MS (marginally significant): $0.10>\mathrm{P}>0.05, *$ : $<<0.05$, **: P<0.01, ***: $\mathrm{P}<0.01$.

Eciniscoidae [6] the trehalose level seems to be affected by desiccation. Still, all these tardigrade species are very tolerant to desiccation. Thus, as concluded by Hengherr et al. [6], there seems to be an evolutionary divergence in the function of trehalose in tardigrades with respect to desiccation. The induction of trehalose observed exclusively in species of the Macrobiotidae family indicates a possible specific function connected with desiccation, but the nature of such a function is currently unknown. The possible role of trehalose in desiccation-tolerant animals has been much discussed (e.g., [12]), but without a final conclusion. Most popular has been the suggestions that trehalose may provide a structural substitute for water in membranes of the desiccated animal ("Water replacement hypothesis" [17]), and that trehalose may establish a structurally stable glassy state in the dry organism [18]. However, it is clear that trehalose is not a necessary component to obtain desiccation tolerance, since there are desiccation tolerant organisms that lack this sugar completely [13]. In addition, while a number of studies have documented a beneficial effect of trehalose in vitro (e.g., [19]), the role of trehalose in vivo in anhydrobiotic organisms is still unclear, and the correlation between desiccation tolerance and trehalose level in, e.g., yeast is not consistent [20]. Recent studies on desiccation tolerance have also emphasized the potential role of stress proteins and their possible complementary or synergistic role together with other compounds such as sugars [12, 21, 22]. Few studies on heat-shock or stress proteins have been reported for tardigrades, but Schill et al. [23] showed that $M$. tardigradum synthesizes the widespread stress protein hsp70 in response to desiccation. Hsp70 is also synthesized in Richtersius coronifer, in response to desiccation, ionizing radiation, and heating ([24], see also Ramløv \& Westh [25] who reported a protein possibly belonging to the hsp70 family in this species).

The level of induced trehalose in Macrobiotidae is much lower than documented in some other desiccation tolerant animals (cysts of Artemia salina, the nematode Aphelenchus avenae, and larvae of the chironomid Polypedilum vanderplanki), where induction of levels up to $15-20 \%$ have been found [3, 7, 8]. It is currently unclear how much trehalose is needed to provide protection against desiccation, and any such estimation will also depend on assumptions of how the sugar acts to provide protection. One such assumption is that trehalose acts by substituting for the removed structural water. Minimum cell concentrations of trehalose for cell survival have been estimated at 0.1-0.2 M, or approx. $10^{10}$ molecules per cell [19]. Unfortunately, there is currently no published information on the total cell number in tardigrades that would allow an estimate of required trehalose content.

In contrast to our study, Hengherr et al. [6] found no evidence of trehalose in $M$. tardigradum, and suggested that this species may have lost the ability to synthesize this sugar. In contrast, our analyses show that this species has in fact low amounts of trehalose. Presence of trehalose $(<0.2 \% \mathrm{dw})$ in $M$. tardigradum was also reported from a Japanese population [26], and we find it unlikely that a single population of this species would lack trehalose completely. Given the low amounts of trehalose documented in the Japanese and Swedish populations, it seems more likely that the analyses by Hengherr et al. [6] may have underestimated the levels of trehalose. This possibility may also be indicated 
by the low trehalose levels reported for the Macrobiotidae species in Hengherr et al. [6], ranging between 0.1 and $0.5 \%$ $\mathrm{dw}$ compared to 2.9 and $2.3 \%$ in M. islandicus and $M$. krynauwi, respectively (this study) and $2.3 \%$ in $R$. coronifer (also a Macrobiotidae species) [5]. The reason for these deviating estimates in trehalose levels deserves further investigation.

The finding in this study, and in Hengherr et al. [6], that some tardigrades with anhydrobiotic capacity do not increase production of trehalose when dehydrated (although it is present in the cells in small amounts), while other tardigrades do so, supports the view that a variety of biochemical solutions to the problem of desiccation tolerance have evolved. It also emphasizes the importance of investigating several populations and species in order to obtain a general picture of the mechanisms behind desiccation tolerance. Desiccation-tolerant tardigrades are found in the two classes of tardigrades, heterotardigrades and eutardigrades, and in all species analyzed so far trehalose has been found. Thus, the ability to synthesize trehalose must represent an ancient trait in tardigrades. The role of this sugar, however, seems to have diverged in the course of evolution, since the connection between trehalose level and induction of desiccation clearly differs among different tardigrades. An important scientific task in the future will therefore be to analyze the presence and dynamics of trehalose in other higher taxa of tardigrades, in order to reveal the taxonomic levels at which specific mechanisms are fixed.

\section{CONCLUSIONS}

Our study confirms previous reports showing an induction of trehalose in tardigrades of the family Macrobiotidae. It also shows that one species previously reported as lacking trehalose, $M$. tardigradum, indeed has trehalose in low amounts, but does not increase the level of this sugar in connection with desiccation. Our current knowledge documents trehalose in both classes of tardigrades (Heterotardigrada, Eutardigrada), and in three out of four orders (Echiniscoidea, Paracaela, Apochaela). Of considerable interest will be to investigate if also tardigrades of the order Arthrotardigrada have trehalose. Arthrotardigrades consist of only marine species, none of which are known to be desiccation tolerant. Also of interest will be to look closer at the families within the order Parachaela, in order to reveal if species within other families than Macrobiotidae show increased levels of trehalose when desiccated.

\section{ACKNOWLEDGEMENTS}

We thank H. Ramløv for valuable advice on trehalose analyses, and M. Kjellman for assisting in running the analyses. We also thank Biomedicinskt Centrum, Lund, for providing the micro balance equipment, and Pär Hallgren for help with the gas chromatograph equipment.

\section{REFERENCES}

[1] Crowe JH, Lois LM, Carpenter JE, et al. Anhydrobiosis: cellular adaptation to extreme dehydration. In: Dantzler WH, Ed. Handbook of Physiology, Sect. 13: Comparative physiology. Oxford: Oxford University Press 1997; pp. 1445-1477.
[2] Clegg JS. Cryptobiosis - a peculiar state of biological organization. Comp Biochem Physiol 2001; 128B: 613-24.

[3] Madin KAC, Crowe JH. Anhydrobiosis in nematodes: carbohydrate and lipid metabolism during dehydration. J Exp Zool 1975; 193: 335-42.

[4] Behm C. The role of trehalose in the physiology of nematodes. Int J Parasitol 1997; 27: 215-29.

[5] Westh P, Ramløv H. Trehalose accumulation in the tardigrade Adorybiotus coronifer during anhydrobiosis. J Exp Zool 1991; 258: 303-11.

[6] Hengherr S, Heyer AG, Köhler H-R, Schill RO. Trehalose and anhydrobiosis in tardigrades - evidence for divergence in responses to dehydration. FEBS J 2007; 275: 281-8.

[7] Clegg JS. The origin of trehalose and its significance during the emergence of encysted dormant embryos of Artemia salina. Comp Biochem Physiol 1965; 14: 135-43.

[8] Watanabe M, Kikawada T, Minagawa N, Yukuhiro F, Okuda T. Mechanism allowing an insect to survive complete dehydration and extreme temperatures. J Exp Biol 2002; 205: 2799-802.

[9] Webb SJ. Bound water in biological integrity. Springfield, IL: Thomas 1965.

[10] Sussich F, Skopec C, Brady J, Cesàro A. Reversible dehydration of trehalose and anhydrobiosis: from solution state to an exotic crystal. Carbohydr Res 2001; 334: 165-76.

[11] Crowe JH, Crowe LM, Oliver AE, Tsvetkova N, Wolkers W, Tablin F. The trehalose myth revisited: introduction to a symposium on stabilization of cells in the dry state. Cryobiology 2001; 43: 89-105.

[12] Crowe JH, Crowe LM, Wolkers W, et al. Stabilization of dry mammalian cells: lessons from nature. Integr Comp Biol 2005; 45: 810-20.

[13] Lapinski J, Tunnacliffe A. Anhydrobiosis without trehalose in bdelloid rotifers. FEBS Lett 2003; 553: 387-90.

[14] Tunnacliffe A, Lapinski J. Resurrecting Van Leeuwenhoek's rotifers: a reappraisal of the role of disaccharides in anhydrobiosis. Phil Trans R Soc Lond 2003; 358B: 1755-71.

[15] Caprioli M, Krabbe Katholm A, Melone G, Ramløv H, Ricci C, Santo N. Trehalose in desiccated rotifers: a comparison between a bdelloid and a monogonont species. Comp Biochem Physiol 2004; 139A: 527-32.

[16] Jönsson K I, Borsari S, Rebecchi L. Anhydrobiotic survival in populations of the tardigrades Richtersius coronifer and Ramazzottius oberhaeuseri from Italy and Sweden. Zool Anz 2001; 240: 419-23.

[17] Clegg JS. The physical properties and metabolic status of Artemia cysts at low water contents: the "Water Replacement Hypothesis". In: Leopold AC. Ed. Membranes, Metabolism, and Dry Organisms. London: Comstock Publication Association 1986; pp. 169-187.

[18] Sun WQ, Leopold AC. Cytoplasmic vitrification and survival of anhydrobiotic organisms. Comp Biochem Physiol 1997; 117A: 327-33.

[19] Chen T, Acker JP, Eroglu A, et al. Beneficial effect of intracellular trehalose on the membrane integrity of dried mammalian cells. Cryobiology 2001; 43: 168-81.

[20] Ratnakumar S, Tunnacliffe A. Intracellular trehalose is neither necessary nor sufficient for desiccation tolerance in yeast. FEMS Yeast Res 2006; 6: 902-13.

[21] Ma X, Jamil K, MacRae TH, et al. A small stress protein acts synergistically with trehalose to confer desiccation tolerance on mammalian cells. Cryobiology 2005; 51: 15-28.

[22] Lins RD, Pereira CS, Hünenberger PH. Trehalose-protein interaction in aqueous solution. Protein Struct Funct Bioinformatics 2004; 55: 177-86.

[23] Schill RO, Steinbrück GHB, Köhler H-R. Stress gene (hsp70) sequences and quantitative expression in Milnesium tardigradum (Tardigrada) during active and cryptobiotic stages. J Exp Biol 2004; 207: 1607-13. 
[24] Jönsson KI, Schill RO. Induction of Hsp70 by desiccation, ionising radiation and heat-shock in the eutardigrade Richtersius coronifer. Comp Biochem Physiol 2007; 146B: 456-60.

[25] Ramløv H, Westh P. Cryptobiosis in the Eutardigrade Adorybiotus (Richtersius) coronifer: tolerance to alcohols, temperature and de novo protein synthesis. Zool Anz 2001; 240: 517-23.
[26] Horikawa DD, Sakashita T, Katagiri C, et al. Radiation tolerance in the tardigrade Milnersium tardigradum. Int J Radiat Biol 2006; 82: 843-8.

[27] Crowe JH. The physiology of cryptobiosis in tardigrades. Mem Ist Ital Idrobiol 1975; 32 (Suppl): 37-59.

Received: October 14, 2009

(C) Jönsson and Persson; Licensee Bentham Open.

This is an open access article licensed under the terms of the Creative Commons Attribution Non-Commercial License (http://creativecommons.org/licenses/by-nc/3.0/) which permits unrestricted, non-commercial use, distribution and reproduction in any medium, provided the work is properly cited. 